\title{
PERAN UNIVERSITAS DALAM PENGEMBANGAN INDUSTRI KECIL UNTUK MENINGKATKAN DAYA SAING EKONOMI LOKAL DI POLEHAN MALANG
}

\author{
Vidya Purnamasari ${ }^{1)}$, Vika Annisa Qurrata ${ }^{2)}$, Sudjatmiko ${ }^{3)}$ \\ ${ }^{1,2)}$ Fakultas Ekonomi, Universitas Negeri Malang \\ 3)Jurusan Teknik Mesin, Universitas Merdeka Malang \\ Email: 1vidya.purnamasari.fe@um.ac.id
}

\begin{abstract}
Abstrak
The majority of Small and Medium Enterprises (SMEs) in Malang is facing several problems, namely the lack of technology and innovation in terms of quality in production and marketing. In order to improve the competitiveness of the local economy of SMEs in Polehan Village, Malang State University through DRPM funding, it provides facilities assistance, online marketing training and business management. This activity is carried out with the intention that SMEs can be more competitive and independent for business development. In detail, the form of activities is to increase the application of science and technology in society through the design of operational training for large ball sewing machines, marketing through the Tokopedia marketplace, and business management. The results that have been achieved are increased marketing so that products / goods in the form of: footwear made from cow, sheep and snake skin can be distributed evenly through ecommerce. E-commerce used is the marketplace and Google MyBusiness which are currently in great demand by consumers.
\end{abstract}

Keywords: Role of the University, small industry development, enhancement of local economic competitiveness

\section{PENDAHULUAN}

Ketatnya persaingan di dunia fashion dapat dipengarui terutama dari segi desain dan harga yang sangat kompetitif menjadi pertimbangan utama bagi para konsumen alas kaki wanita. Hal ini membuat para produsen saling berlomba untuk memenui keingginan konsumen secara keseluruan yang sedang berkembang. Sehingga diperlukan kreativitas dan inovasi baru dibidang produk kulit alas kaki yang tetap menjaga nilai estetika fungsi, desain material, kualitas produk dan finishing produk. Persaingan yang dihadapi oleh usaha kecil tidak hanya di bidang produksi saja tetapi juga dalam hal pemasaran. Pemasaran yang selama ini dilakukan oleh usaha kecil hanya pada bidang offline saja. Hal ini menjadikan usaha kecil terkesan usang dan out of date. Padahal industri fashion selalu berkembang dan menjadikannya cocok dipasarkan secara online. Hal ini semakin didukung oleh data bahwa Indonesia merupakan negara dengan pertumbuhan e-Commerce tertinggi di dunia. Beberapa tahun terakhir, makin banyak pelaku usaha, baik perusahaan besar maupun ritel, beralih atau mengembangkan usaha ke arah digital. (Utomo, et. al, 2019)

Usaha kecil dan menengah menjadi sangat penting untuk melakukan inovasi dan menghasilkan produk berkualitas tinggi untuk berhasil dan kompetisi global. Produk yang dihasilkan harus memiliki ciri khas dan unik sehingga dapat diterima oleh pasar dan bersaing dengan kompetitor (Hartini, 2012). Berdasarkan data Hootsuite We Are Social (2019) total populasi yang menggunakan internet dan media sosial meningkat $1 \%$ atau sekitar 3 juta populasi dari tahun 2018. Data Sensus Ekonomi 2018 dari Badan Pusat Statistik (BPS) menyebutkan, industri e-Commerce Indonesia dalam sepuluh tahun terakhir tumbuh sekitar tujuh belas persen dengan total jumlah usaha e-Commerce mencapai 26,2 juta unit. Sebanyak 73 persen pengguna internet di Indonesia mengakses internet melalui perangkat selular. Angka ini diperkirakan akan terus bertambah dalam lima tahun ke depan. Bank Indonesia (BI) melansir belanja online masyarakat Indonesia mencapai Rp75 triliun di sepanjang tahun lalu. Jika dibagi secara rata-rata pengguna internet yang berbelanja secara online, artinya per orang menghabiskan Rp3 juta per tahun.

Dengan semakin meningkatnya pengguna internet, maka sarana pemasaran juga akan lebih efektif menggunakan e-commerce. E-commerce merupakan basis dari $m$-commerce yang terdiri dari Business to Busines (B2B) dan Business to Costumer $(B 2 C)$. B2B merupakan aplikasi e-commerce antar bisnis, sedangkan B2C merupakan aplikasi ecommerce antara bisnis atau perusahaan dengan konsumen (Turban, 2001). Dengan memanfaatkan $e$ commerce bagi kegiatan usaha, maka pengrajin akan 
mempunyai peluang untuk menjangkau pasar yang luas bahkan global dengan strategi pemasaran one-toone-marketing, sehingga keuntungan yang akan diperoleh semakin besar. Untuk mendukung peningkatan permintaan yang dapat dibentuk dari maksimalisasi pemasaran, maka UKM perlu meningkatkan sarana produksi melalui penerapan teknologi tepat guna. Pemanfaatan teknologi informasi mempunyai dampak positif terhadap strategi manajemen (Adeosun dan Adetunde, 2009). Penggunaan teknologi informasi dapat menjadikan sebuah kekuatan dalam menentukan strategi serta dapat digunakan sebagai alat bagi organisasi bisnis dalam memberikan keuntungan pada aspek promosi dan kekuatan daya saing (Buhalis, 2003). Teknologi informasi juga memberikan beberapa keuntungan bagi dunia bisnis seperti mengurangi biaya serta meningkatkan kemampuan dunia usaha dalam melakukan koordinasi dengan pihak luar (Alexander, 2002).

Malang sebagai salah satu kota dengan penjualan online tertinggi di Indonesia ternyata juga menyimpan beberapa permasalahan pada UKM nya. Beberapa permasalahan terjadi di Kelurahan Polehan. Pertama, minimnya sarana dalam inovasi industri usaha kecil. Alat-alat yang dimiliki oleh UKM kebanyakan masih sederhana sehingga kebanyakan produk yang dihasilkan menggunakan alat-alat yang manual. Hal ini membuat waktu yang dibutuhkan dalam menyelesaikan produk-produk tersebut menjadi lama. Selain itu, dengan alat yang masih manual menjadikan tingkat kerapian dari produk tersebut sering kurang. Kedua, pemasaran yang dilakukan oleh pemilik masih sangat sederhana. Mereka masih mengandalkan marketing dari mulut ke mulut (word of mouth) serta penjualan secara langsung (direct selling). Hal ini akhirnya membatasi sasaran pemasaran mereka. Sebenarnya mereka sudah memiliki akun sosial media untuk sarana pemasaran. Hanya saja mereka jarang menggunakan sehingga mereka tidak banyak dikenal. Selain itu, dengan belum terkenalnya mereka membuat calon pembeli kurang percaya. Berdasarkan permasalahan diatas maka dibutuhkan peranan universitas untuk meningkatkan daya saing ekonomi lokal di UKM tersebut.

\section{METODE KEGIATAN}

Sasaran pelatihan ini adalah UKM perajin sepatu kulit yang berlokasi di Polehan Malang dengan jumlah 25 orang perajin. Pelatihan dan pendampingan dilaksanakan dalam 3 kali pertemuan dengan total waktu selama 1 bulan. Metode dalam pelatihan ini menggunakan partisipatory research yakni proses belajar bersama antara peneliti dengan kelompok masyarakat untuk meningkatkan pemahaman secara kritis terhadap persoalan-persoalan yang dihadapinya dan prosedur penyelesaian permasalahan yang dilakukan antara lain :

1. Melakukan survey dan pengumpulan data. Survey dan pengumpulan data digunakan utuk mendapatkan informasi yang lengkap tentang kendala-kendala yang dihadapi pelaku usaha dalam memasarkan produk dilapangan. Teknik yang dilakukan dalam mengumpulkan data didapatkan melalui wawancara dengan pengrajin. Melalui kegiatan wawancara ini, didapatkan informasi terkait jumlah sepatu yang dapat diproduksi, omset yang telah didapatkan, kisaran jumlah calon konsumen potensial serta omset penjualan sebelum adanya pelatihan.

2. Melakukan analisis hasil survey. Data yang didapatkan melalui wawancara kemudian selanjutnya akan dianalisis untuk menentukan langkah selanjutnya yang harus ditempuh oleh tim pengabdian demi menyelesaikan masalah yang dihadapi oleh pegusaha.

3. Tim pengabdian melakukan pemberian mesin jahit benang besar. Mesin jahit yang digunakan selama ini masih sangat sederhana karena manual. Mesin jahit sederhana tersebut memiliki banyak kekurangan seperti produk yang dihasilkan tidak rapi serta tidak banyak variasi. Mesin jahit sederhana ini masih bisa digunakan akan tetapi menjadikan waktu pembuatan sepatu lama sehingga tidak efisien. Selain itu ketidakrapian produk yang dihasilkan membuat waktu pembuatan menjadi lama karena berkalikali melakukan perbaikan produk. Rencana mesin yang akan di berikan adalah mesin benang besar sehingga produk yang dihasilkan bisa menjadi lebih rapi serta bisa memberikan banyak variasi produk.

4. Tim pengabdian mengadakan pelatihan $e$ commerce. Pelatihan e-commerce yang nantinya akan digunakan untuk memasarkan produk sepatu dilakukan dalam beberapa tahap. Tahapan pertama dimulai dengan perkenalan ragam jenis marketplace yang dapat digunakan untuk pemasaran online. Selanjutnya, pelaku usaha akan dilatih untuk dapat membuat akun pada masing-masing media sosial kemudian dilanjutkan dengan pelatihan cara mengoperasikannya. Beberapa jenis sosial media yang akan diajarkan dalam pelatihan ini antara lain adalah Tokopedia dan Google MyBusiness. Apabila pelaku usaha telah mengusai 
pengoperasian beberapa marketing digital, dalam tahapan selanjutnya UKM akan diminta untuk mempraktekkan dari hasil yang diajarkan.

5. Tim pengabdian mengadakan pelatihan manajemen usaha. Pelatihan ini diberikan pada tahapan yang paling akhir karena setelah produksi dan marketing meningkat maka UKM akan membutuhkan manajemen yang baik untuk usahanya. Pelatihan ini meliputi kemampuan pengelolaan keuangan dengan akses lembaga keuangan pemberi modal, serta memisahkan pengelolaan keuangan usaha dan pribadi dan pemberian informasi syarat serta proses dalam pembuatan standar laporan keuangan UKM dalam akses kredit modal dari lembaga Bank/Non Bank

6. Metode yang digunakan pada tahap akhir adalah melakukan evaluasi untuk mengetahui peningkatan daya saing UKM yang terjadi setelah diadakannya kegiatan pelatihan. Indikator yang menjadi tolak ukur kesuksesan adalah adanya jumlah peningkatan produksi, bertambahnya calon pembeli potensial melalui marketplace, bertambahnya calon konsumen potensial yang mendatangi UKM langsung ke lokasi karena penggunaan Google MyBusiness, kemampuan membuat manajemen usaha, meningkatnya kemampuan dalam mengelola keuangan dan adanya peningkatan omset usaha dalam jangka waktu 2 bulan setelah pengabdian dilakukan.

\section{HASIL DAN PEMBAHASAN}

Dalam beberapa kali pelatihan, hal pertama yang dilakukan adalah pelatihan operasional mesin jahit bola besar. Dalam tahap ini, UKM diberikan pelatihan penggunaan mesin jahit bola besar agar hasil dari produksi menjadi maksimal tingkat kerapiannya. Selain itu, pelatihan ini juga memberikan cara-cara perawatan mesin jahit bola besar agar mesin tersebut menjadi awet.

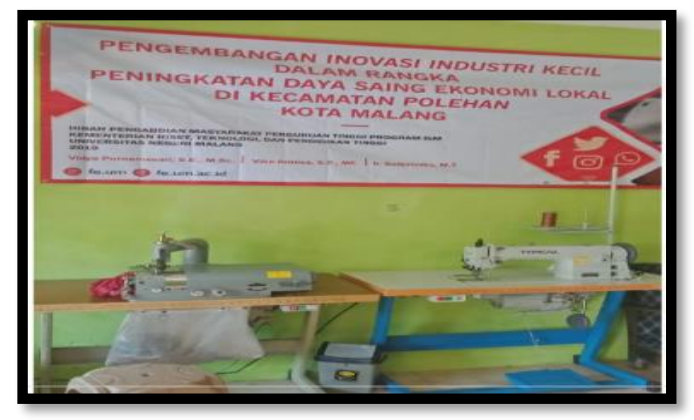

Gambar 1. Mesin Jahit Bola Besar yang diberikan pada UKM

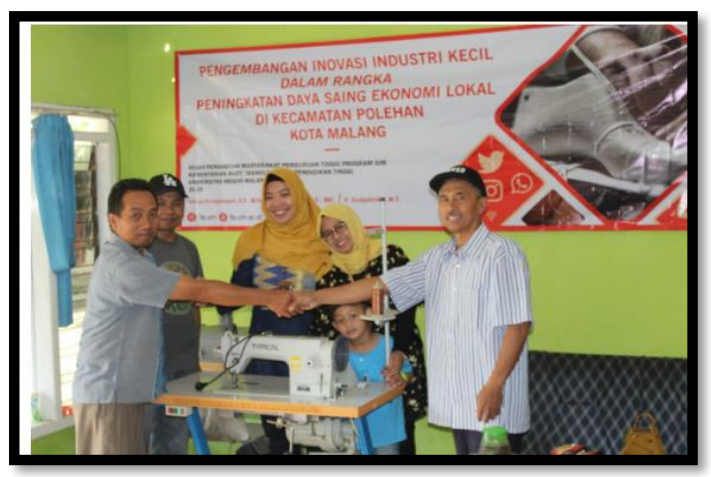

Gambar 2. Proses Penyerahan Mesin Jahit Bola Besar Pada UKM

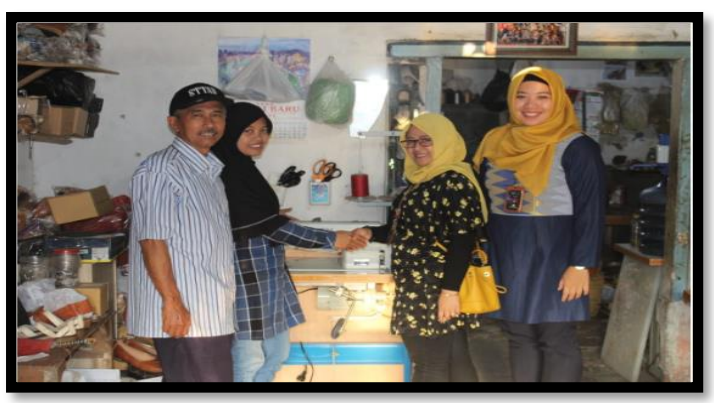

Gambar 3. Proses Penyerahan Mesin Jahit Bola Besar Pada UKM

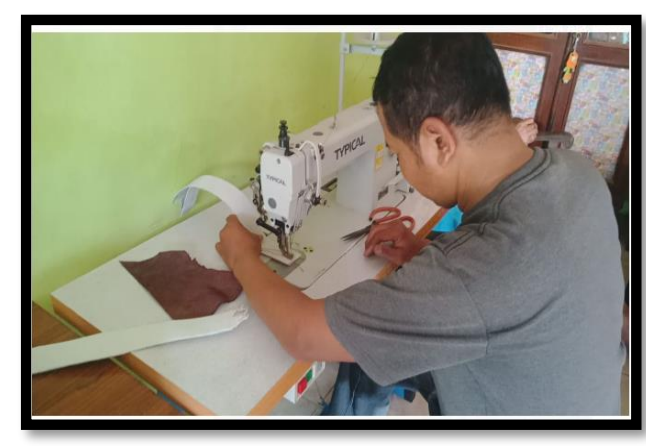

Gambar 4. Proses Mencoba Mesin Jahit Bola Besar

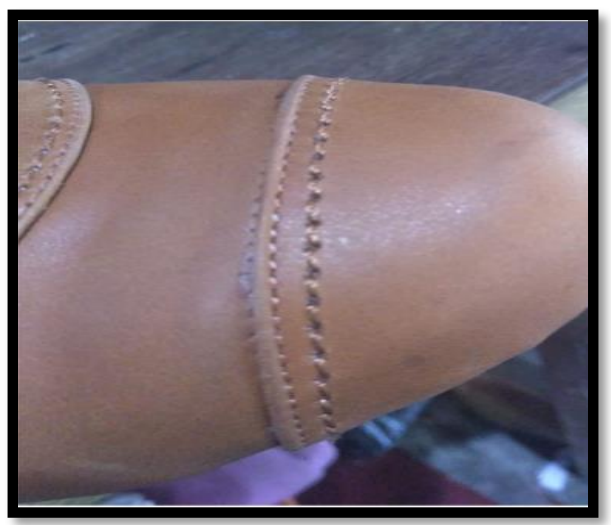

Gambar 5. Hasil Jahit Benang Besar yang Diaplikasi pada Sepatu 
Pada pertemuan kedua adalah perkenalan ragam jenis digital marketing yang dapat digunakan untuk pemasaran online. Dalam tahap perkenalan ini akan dipaparkan kelemahan dan kelebihan masing-masing digital marketing sehingga UKM dapat menentukan preferensi tentang digital marketing yang akan digunakan untuk pemasaran. Selanjutnya, pelaku usaha akan dilatih untuk mendaftarkan usahanya pada marketplace Tokopedia serta di Google MyBusiness kemudian dilanjutkan dengan pelatihan cara mengoperasikannya.

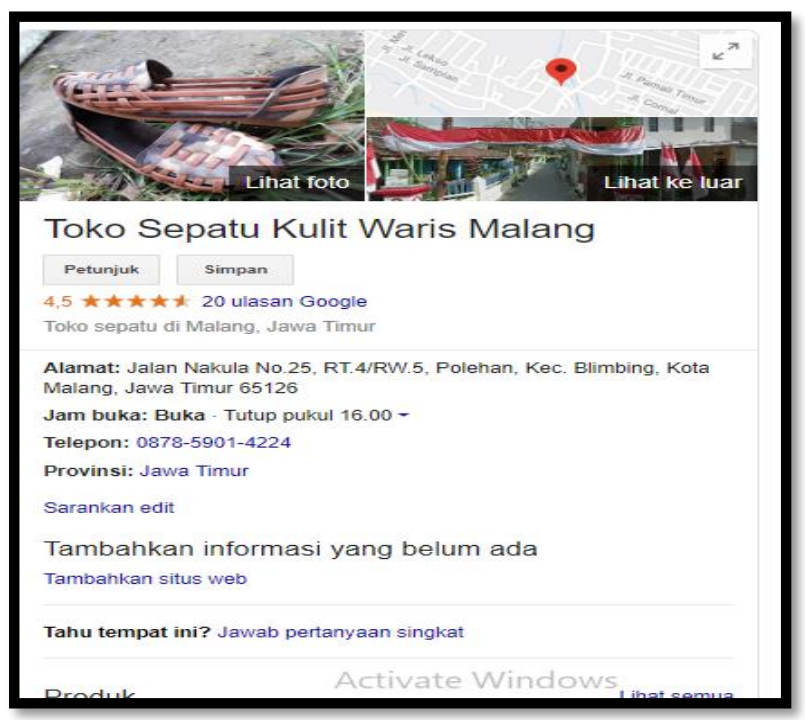

Gambar 6. Contoh GoogleMyBusiness UKM yang dibuat

Setelah para UKM dirasa telah menguasai tahap pengoperasian dasar, selanjutnya pengusaha akan dilatih untuk memanfaatkan semua fitur pada masingmasing marketplace serta akan diberikan tips dan trik dalam memaksimalkan promosi. Beberapa jenis marketplace yang akan diajarkan dalam pelatihan ini antara lain adalah Tokopedia. Selain itu, UKM juga didaftarkan pada akun Google MyBusiness yang memiliki fungsi untuk mempermudah konsumen dalam mencari lokasi usaha UKM. Apabila pelaku usaha telah mengusai pengoperasian Tokopedia, dalam tahapan selanjutnya UKM akan diminta untuk melengkapi akun Google MyBusiness yang dibuat.

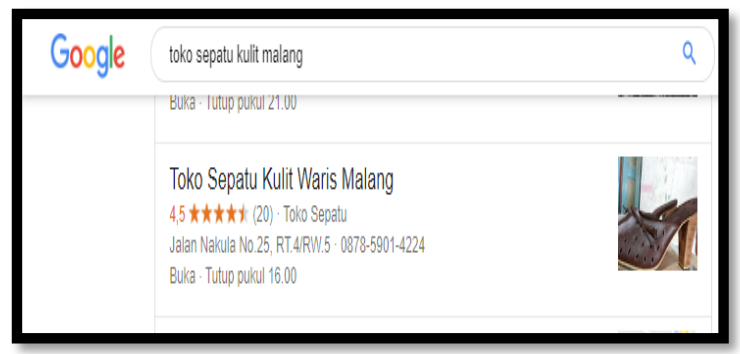

Gambar 7. Brand UKM sudah bisa listing di Google
Hasilnya adalah bahwa UKM telah listing di Google MyBusiness sehingga memudahkan konsumen untuk mencari toko fisik. Beberapa keuntungan mendaftarkan bisnis di Google MyBusiness adalah dipromosikan oleh Google Maps, mendapat revies tentang bisnis, dan meningkatkan pengunjung toko store/toko fisik/offline. Sementara itu, pelatihan ketiga adalah pelatihan manajemen usaha.

Setelah kegiatan pendampingan selesai, evaluasi program dilakukan dengan melihat beberapa aspek, antara lain:

a. Adanya jumlah peningkatan barang yang diproduksi serta perbaikam kualitas oleh UKM dikarenakan kemudahan dalam memproduksi.

b. Bertambahnya calon konsumen potensial yang dimiliki oleh UKM karena penggunaan media sosial sebagai alat untuk mempromoskan produk alas kaki meningkatkan jumlah calon konsumen potensial mencapai rata-rata 170 orang. Metode pemasaran yang awalnya hanya mengandalkan metode direct selling menciptakan batasan dalam ruang lingkup pangsa pasar. Pergeseran metode penjualan melalui penggunaan marketplace terbukti dapat meminimalisir batasan-batasan tersebut sehingga calon konsumen potensial dapat diperoleh tidak hanya dalam skala nasional, tetapi juga internasional.

c. Bertambahnya calon konsumen potensial yang mendatangi UKM langsung ke lokasi karena penggunaan Google MyBusiness sebagai alat untuk mempromosikan produk alas kaki. Google MyBusiness terikat dengan Google Maps sehingga memudahkan konsumen untuk mncari lokasi UKM

d. Para peserta kegiatan pelatihan UKM mampu membuat manajemen usaha yang saat ini sedang dikembangkannya sehingga mempunyai nilai lebih dalam daya saing, serta membuat mitra usaha dengan lembaga maupun pengusaha lainnya.

e. Meningkatkan kemampuan dalam mengelola keuangan dengan akses lembaga keuangan pemberi modal, serta memisahkan pengelolaan keuangan usaha dan pribadi.

f. Perhitungan total omset penjualan yang pada awalnya secara rata-rata hanya mencapai Rp.8.750.000 per minggu, saat ini dapat mencapai hingga Rp.12.000.000 dalam satu minggu. Perhitungan ini diperoleh dengan estimasi harga per pasang alas kaki yang dijual adalah Rp. 175.000, sehingga sesudah pelatihan penggunaan media sosial terdapat peningkatan omset penjualan sebanyak 35 persen. 


\section{Ucapan Terima Kasih}

Penulis menyampaikan terima kasih kepada DRPM dan LP2M Universitas Negeri Malang telah memberikan dukungan secara material terhadap program pengabdian masyarakat ini. Penulis juga berterima kasih kepada Bapak Joko dan Bapak Puji selaku ketua kelompok UKM di kelurahan Polehan Kota Malang.

\section{KESIMPULAN DAN SARAN}

\section{Kesimpulan}

Berdasarkan kegiatan pelatihan yang telah dilakukan diatas, terdapat beberapa kesimpulan yang dapat diambil, antara lain:

1. Peningkatan teknologi tepat guna yang dimiliki oleh UKM melalui pemberian mesin jahit bola besar. Dengan adanya teknologi ini berdampak pada jumlah peningkatan barang yang diproduksi serta perbaikam kualitas oleh UKM dikarenakan kemudahan dalam memproduksi.

2. Peningkatan jumlah produksi karena penggunaan digital marketing, pada akhirnya dapat meningkatkan omset penjualan yang didapatkan oleh pengusaha.

3. Peningkatan kemampuan manajemen usaha yang akan mempermudah UKM memperoleh akses bantuan Bank secara formal

\section{Saran}

Saran disusun berdasarkan temuan pengabdian kepada masyarakat yang telah dibahas. Saran yang dapat dilakukan berdasarkan evaluasi yaitu pembuatan rencana usaha dengan lebih detail, membuat struktur organisasi dan penjadwalan tugas antar pengelola, memperbaiki sistem akuntansi, dan melakukan pemisahan harta. Untuk sistem marketing, saran yang dapat diterapkan adalah meningkatkan review dari pembeli jika mereka mendatangi tempat usaha UKM.

\section{REFERENSI}

Adeosun, T.H., and Adetunde, I.A.,(2009) Strategic Application of Information and Communication Technology for Effective Service Delivery in Banking Industry. Journal of Social Science, 5(1), 47-51.

Alexander, Y.Y. 2002. Enabling E-Commerce Growth Through The Social Construction Of A Virtual Community's Culture. Journal of Electronic Commerce Research,VOL. 3, NO. 4, 2002 Page 279

BPS. (2018). BPS dalam angka

Buhalis, D.(2003) eAirlines: Strategic and Tactical Use of ICTs in the Airlines Industry. Information and Management, 41, 805-825,

Hartini, Sri (2012) Peran Inovasi: Pengembangan Kualitas Produk dan Kinerja Bisnis, jurnal manajemen dan kewirausahaan, vol.14, no. 1

Hootsuite (2019), We Are Social diakses pada https://andi.link/hootsuite-we-are-socialindonesian-digital-report-2019/

Turbin, E., Mc.Clesn, E., Wheterbe, J. (2001) Information Technologyy for Management Making Connections for Strategies Advantage (2nded), John Wiley \& Sons, Inc.

Utomo, Sugeng Hadi; Vika Annisa Qurrata; Vidya Purnamasari; Linda Seprillina. (2019). Peningkatan Omset Penjualan Melalui Media Sosial Pada Usaha Kecil Menengah Alas Kaki Berbahan Kulit. Jurnal Karinov. Vol 2 No.1 